\title{
MODEL PEMBELAJARAN DISCOVERY DENGAN PENDEKATAN KONFLIK KOGNITIF BERORIENTASI PADA KEMAMPUAN BERPIKIR KRITIS PESERTA DIDIK
}

\author{
P. Ayu Suci Lestari*1,3, Gunawan ${ }^{2}$, Kosim² $^{2}$ \\ ${ }^{1}$ Program Magister Pendidikan IPA, Universitas Mataram \\ ${ }^{2}$ Program Studi Pendidikan Fisika, Universitas Mataram \\ ${ }^{3}$ Dinas Sosial Kota Mataram \\ *Email: p.ayusucilestari@unram.ac.id
}

DOI: http://dx.doi.org/10.29303/jpft.v5i1.1161

\begin{abstract}
This study aims to develop an instructional material by discovery model with a cognitive conflict approach that has a positive impact on students' critical thinking skills, especially on temperature and heat material. The development of these instructional materials adapted the 4D (define, design, develop, and disseminate). Teaching materials that have been developed consist of the syllabus, lesson plans, student worksheets, learning materials, and research instruments. The research instrument is an essay test to measure students' critical thinking skills. This product was validated by three expert validators and obtained very high validity criteria. The practicality test was done by observing the implementation of learning accompanied by the questionnaire responses of teachers and students and produces very high practicality criteria. The final value of critical thinking skills students also has high criteria. Therefore, the product developed can be declared valid, practical, and has a positive impact on students' critical thinking skills.
\end{abstract}

Keywords: Discovery, Cognitive Conflict, Critical Thinking

\section{PENDAHULUAN}

Model pembelajaran discovery adalah seperangkat kegiatan pembelajaran yang menekankan peserta didik untuk aktif membuktikan hipotesis dan menemukan konsep secara mandiri melalui suatu kegiatan percobaan/ eksperimen. Pendekatan konflik kognitif adalah pembelajaran yang bertujuan untuk menyamakan sudut pandang peserta didik atas prakonsepsi mereka yang berbeda-beda dengan cara mengkomunikasikan permasalahan yang kontras dengan prakonsepsi mereka sehingga membuat peserta didik menjadi ragu akan kebenaran konsepsi mereka. Kemampuan berpikir kritis adalah proses disiplin bagi seseorang untuk meningkatkan kualitas hasil pemikiran menggunakan teknik cara berpikir yang memungkinkan peserta didik mengevaluasi bukti, asumsi, logika, dan bahasa yang mendasari pernyataan orang lain. Berdasarkan hasil studi pendahuluan yang dilakukan di salah satu SMK Kota
Mataram, diperoleh informasi bahwa perangkat pembelajaran yang diterapkan belum memfasilitasi peserta didik untuk menemukan dan membuktikan konsep fisika. Peserta didik juga cenderung belum fokus untuk mengasah kemampuan berpikir kritis dengan memunculkan konflik kognitif peserta didik. Peserta didik SMK cenderung lebih tertarik pada pembelajaran yang bersifat aplikatif dan disertai dengan praktikum. Akan tetapi, untuk memenuhi hal tersebut diperlukan sarana dan prasarana yang mendukung.

Salah satu penyebab sulitnya pengadaan praktikum di kelas adalah belum tersedianya ruang laboratorium serta ketersediaan alat dan bahan praktikum yang sangat terbatas. Terlebih pada saat penelitian ini dilaksanakan, belum lama sebelumnya pulau Lombok mengalami bencana gempa. Hal tersebut menyebabkan alat dan bahan praktikum yang jumahnya terbatas tersebut menjadi tak layak digunakan karena banyak diantaranya yang mengalami kerusakan. 
Pengimplementasian materi pembelajaran menggunakan praktek secara langsung sangatlah dibutuhkan oleh peserta didik pada jenjang SMK (Emir, 2013), sehingga mampu meningkatkan kemampuan inferensi logika dan kemampuan membangun konsep (Gunawan et al. 2013) serta meningkatkan hasil belajar peserta didik (Lidiana et al. 2018; Husein et al. 2015).

Selain permasalahan mengenai sarana dan prasarana, diperlukan pula perangkat pembelajaran yang mampu memfasilitasi peserta didik untuk berpikir secara mendalam dan berada pada ranah berpikir tingkat tinggi. Hal tersebut didukung oleh Yang (2015); dan Kusumaningrum et al. (2016) yang menyatakan bahwa motivasi dan semangat belajar peserta didik perlu ditingkatkan dengan menerapkan model pembelajaran yang bervariasi.

Hal tersebut tentu dapat diwujudkan dengan melakukan pengembangan pada perangkat pembelajaran yang memacu peserta didik memecahkan masalah-masalah dalam pembelajaran fisika yang mengarahkan peserta didik untuk berpikir secara kritis dan membuktikannya secara langsung dengan melakukan percobaan (Mashami \& Gunawan, 2018; Gunawan \& Liliasari, 2012).

Salah satu model pembelajaran yang mampu memfasilitasi peserta didik dalam menemukan dan membuktikan kosep fisika adalah model pembelajaran discovery. Selain itu, kemampuan peserta didik dapat didukung dengan pendekatan konflik kognitif. Pendekatan ini fokus untuk memunculkan kebingungan pada benak peserta didik sehingga mereka menjadi ragu atas konsepsi yang mereka miliki.

Kombinasi antara model pembelajaran discovery dengan pendekatan konflik kognitif ini dirasa sangat sesuai karena dalam proses pembelajaran dengan menerapkan produk ini, peserta didik akan diarahkan untuk menggali kembali kekeliruan konsep yang mereka miliki dan memfasilitasi peserta didik untuk melakukan percobaan guna membuktikan apakah konsep yang mereka miliki sebelumnya adalah benar atau tidak. Pada proses ini peserta didik akan dipacu untuk berpikir secara mendalam dan mengkritisi pemahaman mereka sebelumnya mengenai konsep fisika. Sehingga dengan dilaksanakannya kegiatan tersebut, peserta didik akan menemukan dan mebuktikan sendiri apakah konsep yang selama ini mereka pamahi sesuai dengan konsep yang dianut oleh para peneliti atau tidak, tentunya hal ini berdasarkan pada kemampuan berpikir kritis peserta didik.

Penelitian yang sebelumnya telah dilaksanakan oleh beberapa peneliti lain menyatakan bahwa selain mampu meningkatkan penguasaan konsep fisika (Sari et al. 2016; Yulianci et al. 2017; Wahyuni et al. 2018), model pembelajaran discovery juga mampu melatih dan mempertajam kemampuan berpikir kritis peserta didik (In'am \& Hajar, 2017; Gunawan, 2017). Selain itu, Fatimah et al. (2015) juga menyatakan bahwa pendekatan konflik kognitif juga berpengaruh positif kemampuan berpikir kritis peserta didik. Berdasarkan uraian tersebut, peneliti tertarik untuk mengembangkan perangkat pembelajaran model discovery dengan pendekatan konflik kognitif. Diharapkan perangkat pembelajaran yang dihasilkan mampu meningkatkan kemampuan berpikir kritis peserta didik.

\section{METODE PENELITIAN}

Penelitian ini merupakan penelitian pengembangan dengan model 4D (define, design, develop, dan disseminate) yang mengkombinasikan model pembelajaran discovery dengan pendekatan konflik kognitif. Kombinasi antara keduanya menghasilkan suatu sintaks baru yang selanjutnya diterapkan di kelas. Adapun 
perangkat yang dikembangkan adalah silabus, RPP (Rencana Pelaksanaan Pembelajaran), LKPD (Lembar Kerja peserta Didik), materi pembelajaran, dan instrumen soal kemampuan berpikir kritis. Penelitian ini baru dilaksanakan hingga uji coba terbatas dan dilanjutkan dengan mengukur kemampuan berpikir kritis peserta didik setelah diberikan perlakuan.

Desain penelitian yang digunakan adalah pre-eksperimental dengan bentuk one-shot case study. Pada desain penelitian ini terdapat suatu kelompok yang diberi perlakuan dan selanjutnya diobservasi hasilnya. Variabel bebas dalam penelitian ini adalah model pembelajaran discovery dengan pendekatan konflik kognitif, sedangkan variabel terikatnya adalah kemampuan berpikir ktitis peserta didik. Hasil yang dimaksud dalam penelitian ini adalah nilai akhir kemampuan berpikir kritis peserta didik (Sugiyono, 2014). Rancangan desain ini dapat dilihat pada Tabel 1 berikut.

Tabel 1. Desain One-Shot Case Study

\begin{tabular}{cc}
\hline Perlakuan & Post Test \\
\hline $\mathrm{X}$ & $\mathrm{O}$ \\
\hline
\end{tabular}

(Sumber: Sugiyono, 2014)

Keterangan:

$\mathrm{X}=$ Perlakuan yang diberikan

$\mathrm{O}=$ Observasi (variabel depanden)

Penelitian ini dilakukan di salah satu

SMK di Kota Mataram tahun ajaran 2018/2019. Kelas yang diteliti adalah kelas X Bs2 yang berjumlah 25 orang peserta didik. Penelitian ini dilaksanakan selama tiga kali pertemuan oleh seorang guru model khusus pada materi pembelajaran suhu dan kalor. Tes kemampuan berpikir kritis ini diberikan pada peserta didik setelah seluruh pertemuan pembelajaran terselesaikan. Instrumen soal yang digunakan adalah soal yang berbentuk uraian sebanyak 5 bitur soal. Masing-masing soal tersebut telah mewakili masing-masing indikator kemampuan berpikir kritis. Indikator tersebut adalah elementary clarification, basic suport, advace clarification, strategy and tacics, dan inference.

Data hasil yang diperoleh tersebut, selanjutnya diklasifikasi dengan tiga cara yaitu klasifikasi nilai peserta didik secara umum dan klasifikasi nilai peserta didik pada masing-masing indikator kemampuan berpikir kritis.

\section{HASIL DAN PEMBAHASAN}

Perangkat pembelajaran model discovery dengan pendekatan konflik kognitif telah melalui proses uji validasi dan uji kepraktisan. Berdasarkan hasil tersebut diperoleh bahwa perangkat yang dikembangkan ini masuk dalam kategori tingkat validitas yang sangat tinggi dan proses pembelajaran dengan merapkan produk ini terbukti memiliki tingkat kepraktisan yang sangat tinggi pula. Tingkat kepraktisan proses pembelajaran tersebut diperoleh berdasarkan data hasil observasi keterlaksanaan pembelajaran dan data hasil respon guru dan respon peserta didik. Pengambilan data kepraktisan dan data nilai akhir kemampuan berpikir kritis peserta didik ini diambil pada kelas yang sama yaitu pada kelas X Bs2. Data kepraktisan yang berupa hasil observasi keterlaksanaan pembelajaran di kelas dilakukan untuk setiap pertemuan. Observasi tersebut dilakukan oleh seorang observer dan proses observasi dilakukan pada saat proses pembelajaran berlangsung. Pengambilan data kepraktisan lainnya yang berupa data hasil respon guru dan peserta didik, dilakukan pada saat seluruh kegiatan pembelajaran pada materi suhu dan kalor tersebut telah terselesaikan. Kegiatan pembelajaran ini berlangsung selama tiga kali pertemuan, sehingga angket respon guru dan angket respon peserta didik ini diberikan pada akhir pertemuan ketiga tersebut.

Setelah semua proses pembelajaran selesai, peneliti juga mengukur tingkat kemampuan berpikir kritis peserta didik 
dengan memberikan kesempatan pada peserta didik untuk menjawab 5 soal uraian yang sebelumnya telah melalui proses uji instrumen soal. Adapun perolehan nilai akhir peserta didik secara umum ini dapat ditunjukkan oleh Tabel 2 berikut.

Tabel 2. Nilai Akhir Peserta didik

\begin{tabular}{cccc}
\hline No. & Kelas & $\begin{array}{c}\text { Jumlah } \\
\text { Peserta } \\
\text { didik }\end{array}$ & Rata-rata \\
\hline 1 & X Bs 2 & 25 & 77.44 \\
\hline
\end{tabular}

Tabel 2 menunjukkan bahwa perangkat pembelajaran yang diterapkan memiliki dampak yang cukup positif pada kemampuan berpikir kritis peserta didik. Nilai rata-rata peserta didik dapat melewati KKM (Kriteria Ketuntasan Minimum). Hal ini disebabkan karena soal-soal uraian yang diberikan didominasi oleh soal-soal yang bersifat aplikatif dan dikaitkan dengan jurusannya. Seperti hasil studi pendahuluan sebelumnya, telah diperoleh informasi bahwa peserta didik cenderung lebih tertarik pada pembelajaran fisika yang bersifat aplikatif dan berkaitan dengan jurusan mereka. Hal tersebutlah tampak pada nilai akhir peserta didik kali ini sehingga nilai yang diperoleh peserta didik tergolong cukup baik.

Selain itu, nilai akhir kemampuan berpikir kritis peserta didik juga diklasifikasikan per indikator. Indikator tersebut secara berurutan adalah elementary clarification, basic suport, advace clarification, strategy and tactics, dan inference. Nilai akhir peserta didik untuk masing-masing indikator kemampuan berpikir kritis tersebut ditunjukkan oleh Gambar 1 berikut. Gambar 1 menunjukkan nilai akhir kemampuan berpikir kritis peserta didik yang diklasifikasi per indikator. Jika berpatokan pada Tabel 2, perolehan nilai kemampuan berpikir kritis peserta didik pada indikator advance clarification masuk dalam kategori sangat tinggi karena berada pada rentang antara 81\%-100\%. Perolehan nilai kemampuan berpikir kritis peserta didik pada indikator elementary clarification, basic suport, strategy and tacics, dan inference berada antara $61 \%-80 \%$ sehingga tergolong dalam kategori yang tinggi.

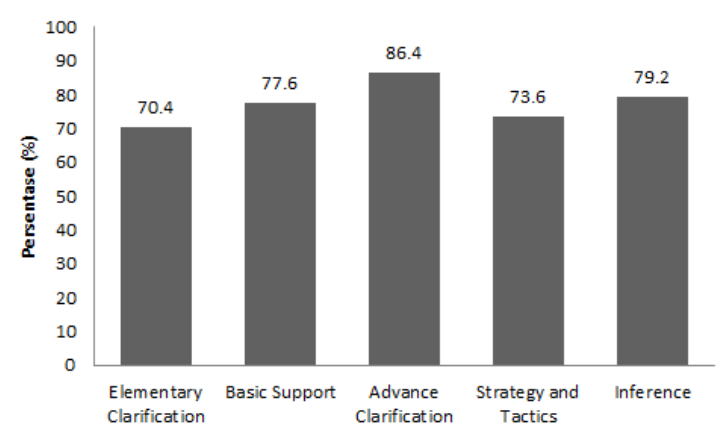

Gambar 1. Nilai Akhir Peserta Didik Per Indikator Kemampuan Berpikir Kritis

Butir soal yang tergolong dalam indikator advance clarification ini adalah butir soal nomor 1, dimana soal tersebut menyajikan grafik perubahan wujud zat lengkap dengan masing-masing fase. Pada soal tersebut peserta didik diminta untuk menjelaskan masing-masing fase pada grafik yang disajikan.

Pada soal dengan indikator inilah peserta didik memperoleh persentase tertinggi, hal tersebut dikarenakan perihal grafik perubahan wujud yang muncul pada soal ini telah seringkali dipaparkan oleh guru pada saat pembelajaran. Dengan demikian, peserta didik dapat dikatakan telah terbiasa memperoleh informasi yang berulang terkait dengan grafik tersebut, sehingga peserta didik memicu daya ingat peserta didik yang cukup tinggi pada tipe soal ini.

Hasil temuan ini bertolak belakang dengan hasil penelitian dari Qurniati et al. (2015) yang menemukan bahwa tidak ada pengaruh model pembelajaran discovery terhadap peningkatan kemampuan berpikir kritis pada indikator advance clarification (memberikan penjelasan lebih lanjut). Hal tersebut tampak pada perolehan nilai peserta didik yang rendah dan hasil perhitungan $\mathrm{N}$ gain yang menunjukkan kemampuan berpikir 
kritis peserta didik pada indikator tersebut berada pada rentang nilai yang lebih rendah dari pengkategotian yang ada.

Pernyataan yang mendukung hasil penelitian ini dinyatakan oleh Zakrah et al. (2015) yang menyatakan bahwa pengembangan perangkat pembelajaran dengan model discovery berpengaruh positif terhadap kemampuan berpikir kritis peserta didik. Implementasi pendekatan konflik kognitif dalam pembelajaran cenderung menempatkan peserta didik pada kategori tinggi, perangkat pengembangannya valid dan praktis, dan layak diaplikasikan pada kegiatan pembelajaran di sekolah (Suryadi et al, 2015; Yonata et al, 2016; Makhrus et al, 2014).

\section{PENUTUP}

Berdasarkan hasil penelitian dan pembahasan yang telah dilakukan, diperoleh bahwa pembelajaran model discovery dengan pendekatan konflik kognitif ini berdampak positif terhadap kemampuan berpikir kritis peserta didik khususnya pada materi suhu dan kalor. Oleh karena itu, dapat disimpulkan bahwa pembelajaran yang mengkombinasikan model discovery dengan pendekatan konflik kognitif ini cocok untuk diterapkan di dalam kelas guna melatih kemampuan berpikir kritis peserta didik.

\section{REFERENSI}

Emir, O. 2013. The Effect of Training on Vocational High School Students in Their Professional Development. Procedia-Social and Behavioral Science 106, 2274-2738.

Fatimah, N., Gunawan, \& Wahyudi. 2016. Pembelajaran Berbasis Masalah dengan Strategi Konflik Kogniti fterhadap Penguasaan Konsep dan Kemampuan Berpikir Kritis Fisika Peserta didik Kelas XI SMKN 1 Lingsar Tahun Pelajaran 2015/2016. Jurnal Pendidikan Fisika dan Teknologi, 2 (4), 183-190.
Gunawan \& Liliasari. 2012. Model Virtual Laboratory Fisika Modern untuk Meningkatkan Disposisi Berpikir Kritis Calon Guru. Cakrawala Pendidikan, 5 (2), 185-120.

Gunawan, G. 2017. Keterampilan Berpikir dalam Pembelajaran Sains. Mataram: Arga Puji Press.

Gunawan, G., Setiawan, A., \& Widyantoro, D. H. 2014. Model Virtual Laboratory Fisika Modern untuk Meningkatkan Keterampilan Generik Sains Calon Guru. Jurnal Pendidikan dan Pembelajaran, 20 (1), 25-32.

Husein, S., Herayanti, L., \& Gunawan. 2015. Pengaruh Penggunaan Multimedia Interaktif Terhadap Penguasaan Konsep dan Keterampilan Berpikir Kritis Peserta Didik Pada Materi Suhu dan Kalor. Jurnal Pendidikan Fisika dan Teknologi, 1 (3), 221-225.

In'am, A., \& Hajar, S. 2017. Learning Geometry through Discovery Learning Using a Scientific Approach. International Journal of Instruction, 10 (1), 55-70.

Kusumaningrum, Indrati, Hidayat, Hendra, Ganefri, Anori, Sartika, \& Dewy, Mega Silfia. 2016. Learning Outcomes in Vocational Education: A Business Plan Development by Production-Based Learning Model Aproach. International Journal of Environmental and Science Education, 11 (18), 11917-11930.

Lidiana, H., Gunawan, \& Taufik, M. 2018. Pengaruh Model Discovery Learning Berbantuan Media PhET Terhadap Hasil Belajara Fisika Pesrta Didik Kelas XI SMAN 1 Kediri Tahun Ajaran 2017/2018. Jurnal Pendidikan Fisika dan Teknologi, 4 (1), 33-39.

Makhrus, M., Nur, M., \& Widodo, W. 2014. Model Perubahan Konseptual dengan Pendekatan Konflik Kognitif (MPK-PKK). Jurnal Pijar MIPA, 9 (1), 20-25. 
Mashami, R. A. \& Gunawan, G. 2018. The Influence of Sub-Microscopic Media Animation on Students' Critical Thinking Skills Based on Gender. Journal of Physics: Conference Series, 1108 (1), 1-7.

Qurniati, D., Andayani, Y. \& Muntari. 2015. Peningkatan Keterampilan Berpikir Kritis Melalui Model Pembelajaran Discovery Learning. Journal Penelitian Pendidikan IPA, 1 (5), 5869.

Sari, P. I., Gunawan, \& Harjono, A. 2016. Penggunaan Discovery Learning Berbantuan Laboratorium Virtual pad Penguasaan Konsep Fisika Peserta Didik. Jurnal Pendidikan Fisika dan Teknologi, 2 (4), 176-182.

Sugiyono. 2014. Metode Penelitian Pendidikan Pendekatan Kuantitatif, Kualitatif, dan $R$ \& D. Bandung: Alfabeta.

Suryadi, A., Ali, M. S. \& Rusli, M. A. 2015. Peranan Strategi Pembelajaran Konflik Kognitif Terhadap Pemahaman Konsep Fisika Peserta Didik Madrasah Aliyah Negeri Pangkep. Jurnal Sains dan Pendidikan Fisika, 11 (2), 141-149.

Wahyuni, S., Kosim, Gunawan. 2018. Pengembangan Perangkat Pembelajaran Fisika Berbasis Inkuiri Terbimbing Berbantuan Eksperimen untuk Meningkatkan Penguasaan Konsep Peserta Didik. Jurnal Pendidikan Fisika dan Teknologi, 4 (2), 240-246.

Yang, Ya-Ting Carolyn. 2015. Virtual CEOs: A Blended Approach to Digital Gaming for Enhancing Higher Order Thinking and Academic Achievement among Vocational High School Students. Computer and Education 81, 281-295.

Yonata, P., Amalia P., \& Hufri. 2016. Desain Perangkat Pembelajaran Fisika Berorientasi Strategi Konflik Kognitif pada Konsep Kalor di Kelas
X SMA/MA. Pillar of Physics Educational 8, 89-96.

Yulianci, S., Gunawan, \& Doyan, A. 2017. Model Inkuiri Terbimbing Berbantuan Multimedia Interaktif untuk Meningkatkan Penguasaan Konsep Fisika Peserta Didik. Jurnal Pendidikan Fisika dan Teknologi, 3 (2), 146-154.

Zakrah, Z., Nur L., \& Kusmivati. 2015. Pengaruh Strategi Pembelajaran Discovery terhadap Kemampuan Berpikir Kritis Peserta Didik Pada Mata Pelajaran IPA Kelas VIII di SMPN 3 Gunungsari Tahun Ajaran 2014/2015. Jurnal Pijar MIPA, 10 (1), 57-63. 